\title{
The Modern Aspects of Anaphylaxis Therapy
}

\author{
Neda M. Puletić1 ${ }^{1}$ Boris Ž. Milijašević1 \\ ${ }^{1}$ Department of Pharmacology, Toxicology and Clinical Pharmacology, Medical Faculty of Novi \\ Sad, Novi Sad, Serbia
}

\section{SUMMARY}

Introduction: Anaphylactic reaction is a most serious allergy where the symptoms may occur shortly after contact with an allergen and can get worse quickly. Therefore, timely and appropriate treatment is of crucial importance.

Methods: In this article, we draw on evidence from publications on the subject of anaphylaxis treatment that we got by searching Google Scholar and PubMed databases. Used articles included: systematic reviews, case reports and randomised controlled trials. We also used World Allergy Organization guidelines for the management and the assessment of anaphylaxis. A literature search with the keywords "anaphylaxis treatment", "anaphylactic shock", and "allergy" identified a number of potentially eligible studies, of which 42 satisfied our eligibility criteria and were therefore included in this review.

Topic: There was evidence regarding the optimum route, dose and site of adrenaline administration, with the latest recommendations indicating the intramuscular route (i.m.) in the mid-outer thigh as the optimum treatment. We found studies suggesting the purpose of applying $\mathrm{H} 1$ and $\mathrm{H} 2$ antihistamines, systemic glucocorticosteroids, calcium and methylxantines to manage anaphylactic shock, recommended doses and mode of administration. With regard to treatment, we focused on acute rather than on long-term management. Further, we have taken into consideration the mechanisms, common triggers and clinical manifestations of anaphylaxis.

Conclusion: Adrenaline represents the first choice drug and it is necessary to be applied as soon as possible. However, there is a controversy regarding the application of the other specified medications in this life-threatening condition.

Keywords: histamine, epinephrine, glucocorticoids, calcium chloride 


\section{INTRODUCTION}

The most widely used definition of anaphylaxis is "a serious allergic reaction that is rapid in onset and may cause death", and occurs suddenly after contact with an allergy-causing substance $[1,2,3,4]$. This acute reaction is an alarming medical emergency as represents life-threatening systemic condition where multiple body organ systems are usually affected (cutaneous, gastrointestinal, respiratory, cardiovascular, or central nervous system) $[1,5,6]$. The condition has been classified on the basis of its severity (mild, moderate or severe anaphylaxis) [7]. Anaphylaxis can further be classified as uniphasic (a single episode occurs), biphasic (the initial episode is followed by a second episode later in time), or protracted. Symptoms and signs experienced during the second phase or recurrent reaction of anaphylaxis are often more severe in nature than that seen with the initial reaction, and thus require aggressive and persistent management.

Anaphylaxis may also be found to have no clear precipitating cause, as seen with idiopathic anaphylaxis (IA) syndromes $[4,8]$. By definition, there is no identifiable antigen responsible for episodes of idiopathic anaphylaxis, and there is no underlying disease in these patients. It has been noted that the patients with IA have elevated levels of plasma and urinary histamine during acute episodes [9]. Exercise-induced anaphylaxis (EIA) is a syndrome characterized by urticaria, symptoms of upper airway obstruction and vascular collapse after exercise. It usually affects teenagers and is often associated with food (Food Dependent EIA), where a particular food or group of foods should be avoided for at least $4 \mathrm{~h}$ prior to exercise [10]. Pumphrey [11], researching fatal anaphylactic reactions in the UK, suggested that exercise may be a common cofactor for recurrent reactions.

The true global rate of occurrence of anaphylaxis remains unknown because of under-recognition by patients and caregivers, under-diagnosis by healthcare professionals, under-reporting and use of a variety of case definitions $[4,12]$. The diagnosis of anaphylaxis is based largely on history and physical findings at the time of the event while laboratory tests available to support the diagnosis (such as plasma histamine level and serum tryptase level ) unfortunately have proved to be disappointing and inapplicable in clinical practice
[13]. Adrenaline, oxygen and fluids are accepted first line treatments, while antihistamines, steroids, glucagon, and aminophylline may be considered second line drugs [14]. The length of time for observing the postanaphylactic patients is suggested to be 4 to 8 hours in most cases, with prolonged observation times for patients with severe or refractory symptoms $[2,14]$. Potential risk factors for severe or fatal anaphylaxis include: history of an anaphylactic reaction; pregnancy; co-morbidities such as asthma (especially if poorly controlled), cardiovascular diseases, mastocytosis, clonal mast cell disorders; and concurrent medications such as $\beta$-blockers and angiotensin-converting enzyme inhibitors $[6,12,15]$.

\section{METHODS}

In this article, we draw on evidence from publications on the subject of anaphylaxis treatment that we got by searching Google Scholar and PubMed databases. Used articles included: systematic reviews, case reports and randomised controlled trials. We also used World Allergy Organization guidelines for the management and the assessment of anaphylaxis. A literature search with the keywords "anaphylaxis treatment", "anaphylactic shock", and "allergy" identified a number of potentially eligible studies, of which 42 satisfied our eligibility criteria and were therefore included in this review.

\section{TOPIC}

\section{Mechanisms, sympthoms and triggers for anaphylaxis}

In immunological terms, anaphylaxis is an example of an immediate, Type-I hypersensitivity reaction [16]. Anaphylactic reaction occurs through an immune mechanism involving interaction between an allergen and allergen specific IgE antibodies. On initial exposure to an antigen in susceptible individuals, IgE is produced and binded to mast cells and basophils. On reexposure, the multimeric antigen cross-links the Fab portions of two surfacebound IgE molecules, inducing the increase of intracellular calcium and the sudden release of chemical mediators (histamine, tryptase, leucotrienes, prostaglandins, platelet activating factor and other inflammatory mediators) into the systemic circulation from the mast cells $[1,17,18]$. An interesting fact is that some of 
the secondary mediators released, in particular by eosinophils, have the ability to inhibit anaphylaxis and thus the process may be selflimiting in less severe reactions. The distinction must be made between anaphylactic and anaphylactoid reaction, where degranulation of mast cells or basophils occurs in non-IgE mediated mechanisms (a direct nonimmunemediated release of mediators or result from direct complement activation) [16]. Clinically it is not possible to make a difference of the two and treatments for both mechanisms are identical $[7,17,18]$. There is a group of authors that use the term "anaphylaxis" to refer to both anaphylactic and anaphylactoid reactions as the clinical expression and final mediators involved are identical [14].

Mediators released are responsible for clinical manifestations, which progress rapidly and can affect most organ systems, including the skin (pruritus, flushing, urticaria, angioedema); eyes (conjunctivitis); the upper (rhinitis and angioedema) and lower (bronchoconstriction with wheezing and dyspnea, cyanosis) airway; the intestinal tract (abdominal pain, nausea, vomiting, diarrhea); the cardiovascular system (tachycardia, hypotension, shock), and can lead to cardiovascular collapse and death [18]. The majority of anaphylactic reactions include skin symptoms, that are noted in more than $80 \%$ of cases $[1,2]$ while the early cutaneous signs of anaphylaxis are often unrecognized in case of anaphylaxis during anesthesia [18]. The four most common anaphylaxis triggers include foods, insect venoms, medications and latex rubber. There are considerable variations in the age-specific etiology of anaphylaxis as medications and insect stings predominate in adults while foods is the most common cause in children $[3,6]$. Individuals over 30 years are more likely to experience hypotensive anaphylaxis with cardiovascular collapse usually a highlighted characteristic, and are at greatest risk of death from insect sting anaphylaxis. In comparison, younger people most often die from food-induced anaphylaxis and fatality is predominantly due to upper and/or lower airway obstruction [13].

Medications indicated as the most common causes of anaphylaxis include: penicillins [19]; muscle relaxants-particularly succinylcholine [20], that is more likely to cause anaphylaxis than nondepolarizing muscle relaxants such as pancuronium or vecuronium) [8]; iodinated contrast media [18]; antituberculosis medications [12]; NSAIDs [12]; protamine [22]. Also, common causes in healthcare settings include chlorhexidine $[18,21]$ and natural rubber latex $[23,24]$.

\section{Acute anaphylaxis episode management}

The management of anaphylaxis includes both the treatment of acute episodes and the implementation of strategies to avoid recurrences [10]. Anaphylaxis treatment begins with a rapid assessment and maintenance of airway, breathing, and circulation [2]. The cornerstones of the treatment are immediate discontinuation of the trigger and early adrenaline administration $[1,18]$.

Adrenaline has a pivotal role as first line therapy for acute anaphylaxis and represents the treatment of choice because the actions of adrenaline reverse all features of anaphylaxis $[12,17,25]$. It has been shown that a prompt administration of adrenaline may be life-saving so it is classified as an essential medication for the treatment of anaphylaxis by the The World Health Organization and should be administered as soon as the anaphylaxis is recognized $[4,12]$. A delay in the administration of adrenaline and too small a dose given for the primary response have been suggested as risk factors for late-phase reactions, complications and fatalities $[4,6,26]$. Patient's blood pressure, cardiac rate and function, respiratory status and oxygenation should be monitored at frequent and regular intervals. Patients in anaphylactic shock should be placed in a recumbent (The Trendelenburg position) with the lower extremities elevated. This accomplishes 2 therapeutic goals: 1) preservation of fluid in the circulation (the central vascular compartment), that is an important step in managing distributive shock; and 2) prevention of the empty vena cava, which can occur within seconds when patients with anaphylaxis suddenly are placed in an upright position.

The next steps include supplemental oxygen, intravenous fluid resuscitation and cardiopulmonary resuscitation with continuous chest compressions. Supplemental oxygen should be administered by face mask or by oropharyngeal airway at a flow rate of $6-8 \mathrm{~L} /$ min to all patients receiving repeated doses of epinephrine and those with respiratory distress [12]. Fluid therapy is recommended alongside adrenaline in order to replace the plasma losses of up to $50 \%$ of the circulatory volume [16]. 
The volume expanders are required in patients who remain hypotensive despite epinephrine administration but the volume given must be tailored to the clinical situation [2,3]. Fluids are given at $10-20 \mathrm{ml} / \mathrm{kg}$ and include: crystalloid solutions (such as normal saline or Ringer's lactate), or colloids (albumin, dextran, gelatin preparations). There are factors favouring the use of colloids in anaphylactic shock [14]. Intravenous fluids and adrenaline have a synergistic effect in the treatment of anaphylaxis. Fall in systolic blood pressure of more than 20 $\mathrm{mm} \mathrm{Hg}$ and tachycardia are features of moderate anaphylaxis and should be treated with 10 $\mathrm{ml} / \mathrm{kg}$ colloid intravenous fluid. If severe cardiovascular collapse occurs, higher volumes $(20 \mathrm{ml} / \mathrm{kg})$ should be infused [27].

In the event of failure of epinephrine and fluid resuscitation to regulate the blood pressure, potent vasopressors administration might be an option [2]. Vasopressors- dopamine, dobutamine, norepinephrine, phenylephrine, or vasopressin can be given although there are no established dosing regimens for any of these medications, because the dose is titrated according to the clinical response [12].

\section{Therapeutic agents in anaphylaxis}

\section{Adenaline}

The beneficial effects of adrenaline include: $\alpha$ adrenoceptors stimulation that increases peripheral vascular resistance and thus improving blood pressure, decreases angioedema and urticaria; $\beta 1$ adrenoceptors stimulation shows both positive inotropic and chronotropic cardiac effects while $\beta 2$ adrenergic effects provide bronchial smooth-muscle relaxation; $\beta$ adrenoreceptors stimulation also increases intracellular cyclic adenosine monophosphate (cAMP) production in mast cells and basophils, whereby inhibits further inflammatory mediator release $[17,18,28]$.

It is worth mentioning that adrenaline has a relatively narrow therapeutic window, so the fact must be considered when planning treatment [10]. A considerable confusion regarding the correct route and dose could be an issue which concerns the use of adrenaline [29]. It has been suggested that i.m. administration of injectable epinephrine is the most preferred route because intramuscular adrenaline is rapidly bioavailable, with peak concen- trations occurring within $10 \mathrm{~min}$ and partly due to reducing the requirement for repeated doses. In patients with cardiac arrest or severe hypotension unresponsive to intramuscular doses of epinephrine, intravenous (i.v.) application is an option $[2,10,18,27]$. Also, it was observed that the subcutaneous (s.c.) administration of adrenaline leads to prolonged but variable absorption related to local vasoconstrictor action and this potential for variability is clearly unacceptable in the critically compromised or shocked patients [14]. Simons and coworkers have shown in their studies that plasma epinephrine concentrations were greater in case of i.m. in comparison with s.c. adrenaline application both in children [30] and in adults [31]. Recommendations for epinephrine dosing by i.m. route is accepted to be $0.01 \mathrm{mg} / \mathrm{kg}$ to a maximum of $0.3 \mathrm{mg}$ in children (for example, $0.7 \mathrm{ml}$ of 1:1000 adrenaline intramuscularly for a $70 \mathrm{~kg}$ adult and 0.3 $\mathrm{ml}$ for a $30 \mathrm{~kg}$ child). If needed, epinephrine may judiciously be repeated in both adults and children. The interval between doses should be $5-30$ minutes $[7,27,28]$ whereby repeated doses of adrenaline are indicated until clinical improvement is achieved [10]. Patients usually respond to 1 or 2 doses [12].

There is a disagreement on the subject of i.v. administration of epinephrine as some clinicians warn that this route of administration is too dangerous and rarely if ever justified, as it may cause greatly increased systolic and diastolic blood pressures with the risks of ischaemia, intracerebral bleeding, cardiac arrhythmias or even infarction. These serious adverse outcomes usually occur when the adrenaline is given too rapidly, inadequately diluted, or in excessive dose [14]. In case of i.v. application, up to $5 \mu \mathrm{g} / \mathrm{kg}$ is recommended, which is a lower dose than with the i.m. route (for example, $3.5 \mathrm{ml}$ of 1:10000 adrenaline for a $70 \mathrm{~kg}$ adult and $1.5 \mathrm{ml}$ for a $30 \mathrm{~kg}$ child). An adrenaline dilution of 1:10 000 or greater (1: $100000)$ is recommended for the i.v. route; half the dose should be given very slowly while monitoring the patient's vital signs and the rest should then be given in small aliquots if there are no adverse effects $[2,27,32]$. Samson et al [2] indicated that continuous low-dose epinephrine infusions might have the advantage over large boluses of epinephrine as represents safer and more effective form of delivery because the dose can be titrated to the desired effect whereby avoiding the potential for acci- 
dental administration.

Although adrenaline remains the drug of first choice, for some patients its therapeutic range is narrow and dosing should be carefully managed. There have been reports of anaphylaxis where the rate of adrenaline injection was inappropriately high whereby this adrenaline overdose caused fatalities. These incorrect treatments should not be seen as detracting from the value of adrenaline in management of severe acute allergic reactions. Therefore, serious concerns exist in terms of competence of doctors who may have to treat anaphylactic reactions. They have to be able to recognize the indications for adrenaline and to know the correct dose and route of administration [32].

There have been attempts to develop inhaled epinephrine dosage forms $[17,33,34,35]$. The advantages of this mode of application involve: simplicity of application, the advantage of direct contact with the larynx (where life-threatening edema may occur) and rapid relief of associated bronchospasm. It has been shown that appreciable quantities of epinephrine may be absorbed by the inhaled route if adequate doses are given. However, the systemic absorption showed considerable individual variation and this might be more marked in patients with anaphylaxis or acute airways obstruction as bronchoconstriction may obstruct the availability of inhaled adrenaline [33]. Mellem et al [34] have demonstrated that inhalation gives a faster absorption of adrenaline than subcutaneous injection. There were also less intersubject variations in plasma adrenaline levels after inhalation indicating that inhalation gives a more reliable absorption.

\section{Antihistamines}

Antihistamines represent second-line drugs, commonly used as an adjuvant therapy, which are given in order to minimize the clinical impact of histamine release. Antihistamines are expected to be useful in attenuating the cutaneous manifestations, angioedema, nasal and eye symptoms, but do not affect the hypotension , airway obstruction, gastrointestinal symptoms, or shock $[2,3,12]$. After oral administration, antihistamines have a slow absorption and onset of action and can not block events that occur subsequent to histamine binding to its receptors $[13,36]$.
Antihistamines can be administered intravenously, intramuscularly or orally (depending on the condition of the patient). Treatment with a combination of $\mathrm{H} 1$ and $\mathrm{H} 2$ antagonists has been reported to be more effective than treatment with $\mathrm{H1}$-antagonists alone in the acute management of anaphylaxis , as well as for the prevention of drug induced anaphylactic reactions. It has been proven that $\mathrm{H} 2$ receptor antihistamines such as cimetidine in a dose of $300 \mathrm{mg}$ intravenously are effective in refractory anaphylactic shock unresponsive to adrenaline, fluids, steroids, and H1 receptor antihistamine given intravenously [14]. Yarbrough et al have demonstrated that the anaphylactic shock, caused by cefuroxime and refractory to the usual therapeutic measures, was responsive to treatment with intravenous cimetidine [37]. Antihistamines are of greatest use when the allergic condition is not life threatening, such as in urticaria and angioedema [14].

Diphenhydramine can be given at 25 to $50 \mathrm{mg}$ for adults and $1 \mathrm{mg} / \mathrm{kg}$ (up to $50 \mathrm{mg}$ ) for children [2]. Most guidelines include antihistamines and their usage in the management of acute anaphylaxis is widespread, but controversial [14]. There is a disagreement among the authors regarding the antihistamines application, due to insufficient evidence of their effectiveness and because the side effects that antihistamines may induce $[3,13]$. There are also concerns about potential harmful central nervous system effects, for example: sedation, confusion, somnolence or impairment of cognitive functions caused by first-generation $\mathrm{H} 1$-antihistamines given in usual doses. Also, in infants and young children, paradoxical CNS stimulation can occur $[12,13,14]$. Furthermore, most medications in this large class cannot be administered by injection, with the exception of few first-generation H1-antihistamines [13].The unavailability of parenterally administered second-generation H1-antagonists is a limiting factor for their use in acute anaphylaxis and perioperative prophylaxis [36].

\section{Corticosteroids}

These medications exhibit slow onset of action due to which are not useful in the acute management stage [2]. Theoretical beneficial effects involve: an increase in tissue responsiveness to betaadrenergic agonists, inflammatory me- 
diator synthesis inhibition and prevention of neutrophil and platelet aggregation. The role of steroids in the management of acute anaphylaxis is limited to the prevention of biphasic or shortening protracted reactions. However, still remains unclear whether corticosteroids given for the primary event, have a preventive effect on second reaction $[8,23,26]$ as their efficacy in reducing the risk of late-phase reactions has not been fully proven [10]. It is worth noting that glucocorticoid use for anaphylaxis is increasing and glucocorticoids were reported as even more frequently administered than adrenaline [23]. Oral steroids also form the cornerstone in management of recurrent IA [14]. The dosing of intravenous corticosteroids should be equivalent to 1.0 to $2.0 \mathrm{mg} / \mathrm{kg}$ per dose of methylprednisolone every 6 hours. In case of milder to moderate attacks prednisone can be given oraly, at the dose of $1.0 \mathrm{mg} /$ $\mathrm{kg}$, up to $50[2,6]$. Corticosteroids can cause serious side effects (steroid induced myopathy, sodium and potassium ion flux changes) [14]. Also, it is reported that corticosteroids have caused systemic anaphylaxis themselves [38].

\section{Adjunctive therapy}

Intravenous salbutamol or glucagon administration, or both, should be considered if the patient is on a $\beta$-blocker used and appear to have more frequent and severe anaphylactic reactions, resistant to standard therapy $[14,27,29]$. $\beta 2$-agonists are useful adjuvants in treating bronchospasm associated with anaphylaxis and may be administered by inhalation or intravenously $[10,18]$. Glucagon also might be considered in protracted anaphylaxis: $1 \mathrm{mg}$ boluses up to $3 \mathrm{mg}$ (half doses in children) should be followed by an infusion of $1-5 \mathrm{mg} /$ hour [27].

Aminophylline is useful for severe anaphylactic bronchospasm resistant to adrenaline and steroids. Beneficial effects include stimulation of respiratory muscles, bronchodilatation and pulmonary vasodilatation. The recommended dose is $5-6 \mathrm{mg} / \mathrm{kg}$ intravenously over 30 minutes, with full cardiac monitoring [14]. Slow application of aminophylline is necessary in order to avoid the occurrence or deepening of the already existing hypotension [39].

\section{Calcium}

There are case reports where the authors suggested intravenous calcium application during the anaphylactic reaction, in the form of calcium chloride $[22,40]$ or calcium gluconate, in a dose of $1 \mathrm{~g}$, i.e. $10 \mathrm{~mL}$ of calcium gluconatesolution $10 \%$ [41]. Calcium is considered to be used in anaphylaxis treatment since it has antiallergic effect, reduces cell permeability, dilates coronary blood vessels, it is involved in the coagulation factors activation, reduces neuromuscular excitability and has a positive effect on the heart during systole [39]. Lembeck [42], researching potential therapeutic indications of intravenous calcium, concluded that calcium effects of therapeutic significance, if existent at all, could be assumed only with regard to an anti-anaphylactic effect of the catecholamines released by i.v. injected calcium.

\section{CONCLUSION}

Searching the literature, we did not find a uniform data, but a wide variation in recommendations in terms of dosing and mode of drug administration. The use of intramuscular adrenaline in anaphylaxis is acknowledged as the first line of therapy both in the hospital and in the community. We found that the subcutaneous administration of adrenaline used to be the method of choice in the past while the latest recommendations indicate the intramuscular route in the mid-outer thigh as the most convenient route.

Most publications cited in this article are systematic reviews, largely as a consequence of the lack of randomized controlled studies in this field. This might be due in part to difficulty in implementing randomized controlled trials in an anaphylactic shock, that represents a severe and a potentially life-threatening condition characterized by unpredictable and acute manifestations. Also, there are number of ethical issues related to the conducting of such studies. As a result, most of the guidelines in the management of anaphylaxis are derived from experience including retrospective studies, case reports, and other descriptive literature. This may be a source of confusion and conflict in the medical literature as for the correct dosage and administration route of adrenaline and other medications used in anaphylaxis treatment.

We have noticed that antihistamines 
and corticosteroids are listed as integral part of the therapy of anaphylaxis in all the publications, including the World Allergy Organization guidelines, although some authors suggest that there is little firm evidence about their effectiveness. We found that intravenous calcium application was suggested only in few case reports, while it has not been mentioned in the review articles on the subject of anaphylaxis treatment. Considering more recent guidelines, which do not indicate calcium to be a part of the treatment protocol, we concluded that intravenous calcium administration in the management of anaphylactic shock is abandoned.

\section{REFERENCES}

1. Simons FE, Sheikh A. Anaphylaxis: the acute episode and beyond. BMJ. 2013 Feb 12;346.

2. Sampson HA, Muñoz-Furlong A, Bock SA, Schmitt C, Bass R, Chowdhury BA, Decker WW, Furlong TJ, Galli SJ, Golden DB, Gruchalla RS. Symposium on the definition and management of anaphylaxis: summary report. J Allergy Clin Immunol. 2005 Mar 31;115(3):584-91.

3. Sheikh A, ten Broek VM, Brown SG, Simons FE. $\mathrm{H} 1$-antihistamines for the treatment of anaphylaxis with and without shock. Cochrane Database Syst Rev. 2007 Jan 1;1.

4. Sheikh A, Shehata YA, Brown SG, Simons FE. Adrenaline for the treatment of anaphylaxis: Cochrane systematic review. Allergy. 2009 Feb $1 ; 64(2): 204-12$.

5. Dhami S, Panesar SS, Roberts G, Muraro A, Worm $M$, Bilò $M B$, Cardona V, Dubois $A E$, DunnGalvin A, Eigenmann $P$, Fernandez-Rivas M. Management of anaphylaxis: a systematic review. Allergy. $2014 \mathrm{Feb}$ 1;69(2):168-75

6. Sampson HA. Anaphylaxis and emergency treatment. Pediatrics. 2003 Jun 1;111(Supplement 3):1601-8.

7. Kemp SF, Lockey RF. Anaphylaxis: a review of causes and mechanisms. J Allergy Clin Immunol. 2002 Sep 30;110(3):341-8.

8. Douglas DM, Sukenick E, Andrade WP, Brown JS. Biphasic systemic anaphylaxis: an inpatient and outpatient study. J Allergy Clin Immunol. 1994 Jun 30;93(6):977-85.

9. Wiggins CA, Dykewicz MS, Patterson R. Idiopathic anaphylaxis: classification, evaluation, and treatment of 123 patients. J Allergy Clin Immunol. 1988 Nov 30;82(5):849-55.

10. Muraro A, Roberts G, Clark A, Eigenmann PA, Halken S, Lack G, Moneret-Vautrin A, Niggemann B, Rancé $F$. The management of anaphylaxis in child- hood: position paper of the European academy of allergology and clinical immunology. Allergy. 2007 Aug 1;62(8):857-71.

11. Pumphrey R. Anaphylaxis: can we tell who is at risk of a fatal reaction?. Curr Opin Allergy Clin Immunol. 2004 Aug 1;4(4):285-90.

12. Simons FE, Ardusso LR, Bilò MB, El-Gamal YM, Ledford DK, Ring J, Sanchez-Borges M, Senna GE, Sheikh A, Thong BY. World Allergy Organization guidelines for the assessment and management of anaphylaxis. J Allergy Clin Immunol. 2011 Feb 15;593:1-22.

13. Sheikh A, Ten Broek V, Brown SG, Simons FE. $\mathrm{H} 1$-antihistamines for the treatment of anaphylaxis: Cochrane systematic review. Allergy. 2007 Aug 1;62(8):830-7.

14. Brown AF. Therapeutic controversies in the management of acute anaphylaxis. J Accid Emerg Med. 1998 Mar;15(2):89.

15. Simons F. Anaphylaxis pathogenesis and treatment. Allergy. 2011 Jul 1;66(s95):31-4.

16. Brown AF. Anaphylactic shock: mechanisms and treatment. J Accid Emerg Med. 1995 Jun 1;12(2):89100.

17. McLean-Tooke AP, Bethune CA, Fay AC, Spickett GP. Adrenaline in the treatment of anaphylaxis: what is the evidence?. BMJ. 2003 Dec 6;327(7427):1332.

18. Hepner DL, Castells MC. Anaphylaxis during the perioperative period. Anesth Analg. $2003 \mathrm{Nov}$ 1;97(5):1381-95.

19. Idsoe O, Guthe T, Willcox RR, De Weck AL. Nature and extent of penicillin side-reactions, with particular reference to fatalities from anaphylactic shock. Bull World Health Organ. 1968;38(2):159.

20. Baumann A, Studnicska D, Audibert G, Bondar A, Fuhrer Y, Carteaux JP, Mertes PM. Refractory anaphylactic cardiac arrest after succinylcholine administration. Anesth Analg. 2009 Jul 1;109(1):13740.

21. Beaudouin E, Kanny G, Morisset M, Renaudin JM, Mertes M, Laxenaire MC, Mouton C, Jacson F, Moneret-Vautrin DA. Immediate hypersensitivity to chlorhexidine: literature review. Eur Ann Allergy Clin Immunol. 2004 Apr;36(4):123-6.

22. Roelofse JA, Van Der Bijl P. An anaphylactic reaction to protamine sulfate. Anesth Prog. 1991 May;38(3):99.

23. Choo KJ, Simons F, Sheikh A. Glucocorticoids for the treatment of anaphylaxis. Evid Based Child Health. 2013 Jul 1;8(4):1276-94.

24. Ebo DG, Stevens WJ, De Clerck LS. Latex anaphylaxis. Acta Clin Belg. 1994 Dec;50(2):87-93.

25. Brown AF. Therapeutic controversies in the management of acute anaphylaxis. J Accid Emerg 
Med. 1998 Mar;15(2):89.

26. Lieberman P. Biphasic anaphylactic reactions. Ann Allergy Asthma Immunol. 2005 Sep 30;95(3):21726.

27. Gavalas M, Sadana A, Metcalf S. Guidelines for the management of anaphylaxis in the emergency department. J Accid Emerg Med. 1998 Mar $1 ; 15(2): 96-8$.

28. Simons FE. First-aid treatment of anaphylaxis to food: focus on epinephrine. J Allergy Clin Immunol. 2004 May 31;113(5):837-44.

29. Gompels LL, Bethune C, Johnston SL, Gompels $M M$. Proposed use of adrenaline (epinephrine) in anaphylaxis and related conditions: a study of senior house officers starting accident and emergency posts. Postgrad Med J. 2002 Jul 1;78(921):416-8.

30. Simons FE, Roberts JR, Gu X, Simons KJ. Epinephrine absorption in children with a history of anaphylaxis. J Allergy Clin Immunol. 1998 Jan 31;101(1):33-7.

31. Simons FE, Gu X, Simons KJ. Epinephrine absorption in adults: intramuscular versus subcutaneous injection. J Allergy Clin Immunol. 2001 Nov 30;108(5):871-3.

32. Pumphrey RS. Lessons for management of anaphylaxis from a study of fatal reactions.

Clin Exp Allergy. 2000 Aug 30;30(8):1144-50.

33. Warren JB, Doble N, Dalton N, Ewan PW. Systemic absorption of inhaled epinephrine. Clin Pharmacol Ther. 1986 Dec 1;40(6):673-8.

34. Mellem H, Lande K, Kjeldsen SE, Westheim A, Eide I, Ekholt PF, Boye NP. Faster and more reliable absorption of adrenaline by aerosol inhalation than by subcutaneous injection. $\mathrm{Br} \mathrm{J}$ Clin Pharmacol. 1991 Jun 1;31(6):677-81.

35. Warren JB, Doble N, Dalton N, Ewan PW. Systemic absorption of inhaled epinephrine. Clin Pharmacol Ther. 1986 Dec 1;40(6):673-8.

36. Winbery SL, Lieberman PL. Histamine and antihistamines in anaphylaxis. Clin Allergy Immunol. 2001 Dec;17:287-317.

37. Yarbrough JA, Moffitt JE, Brown DA, Stafford CT. Cimetidine in the treatment of refractory anaphylaxis. Ann Allergy. 1989 Sep;63(3):235-8.

38. Murrieta-Aguttes M, Michelen V, Leynadier F, Duarte-Risselin C, Halpern GM, Dry J. Systemic allergic reactions to corticosteroids. J Asthma. 1991;28(5):329-39.

39. Babić R, Radovanović Z, Mrvić M, Babić D, Marković S, Lekić V. Terapija anafilaktoidnih reakcija na jodno kontrastno sredstvo pri urografiji. Acta med. Median. 2000; 39(3):61-71.

40. Aguilera L, Martinez-Buorio R, Cid C, Arino JJ, Eguilaz JS, Arizaga A. Anaphylactic reaction after atropine. Anaesthesia. 1988 Nov 1;43(11):955-7.

41. Kober BJ, Scheule AM, Voth V, Deschner N, Schmid E, Ziemer G. Anaphylactic reaction after systemic application of aprotinin triggered by aprotinin-containing fibrin sealant. Anesth Analg . 2008 Aug 1;107(2):406-9.

42. Lembeck F, Juan H. Are there therapeutic indications of intravenous injection of calcium gluconate? Arzneimittelforschung. 1975 Oct;25(10):1570-4. 


\title{
Savremeni pristup terapiji anafilaktičkog šoka
}

\author{
Neda M. Puletić ${ }^{1}$, Boris Ž. Milijašević ${ }^{1}$ \\ ${ }^{1}$ Zavod za farmakologiju, toksikologiju i kliničku farmakologiju, Medicnski fakultet Novi sad, Novi Sad, \\ Srbija
}

\section{KRATAK SADRŽAJ}

Uvod: Anafilaktički šok predstavlja najteži oblik alergije, simptomi se najčešće javljaju neposredno nakon kontakta sa alergenom i naglo pogoršavaju. Stoga je blagovremena i tačno definisana odgovarajuća terapija od suštinskog značaja.

Metod: Analizirali smo 42 naučne publikacije na temu tretmana anafilaktičkih reakcija, a koje su dobijene pretraživanjem Google Scholar i PubMed baza podataka pomoću ključnih reči: " terapija anafilakse ", "anafilaktički šok " $i$ "alergija ". Citirani radovi uključuju pregledne članke, studije slučajeva i randomizirane kontrolisane studije. $\mathrm{U}$ radu se oslanjamo i na smernice Svetske Zdravstvene Organizacije za procenu i terapiju anafilakse.

Tema: Pronašli smo podatke koji se odnose na doziranje i način primene adrenalina i prema najnovijim preporukama, optimalan put primene je intramuskularna (i.m.) aplikacija u butni mišić. Pored toga, ukazujemo na svrhu i put primene $\mathrm{H} 1 \mathrm{i} \mathrm{H} 2$ antihistaminika, sistemskih kortikosteroida, metilksantina i kalcijuma. Osvrnuli smo se i na najčešće uzročnike, imunološke mehanizme i kliničke manifestacije anafilaktičke reakcije.

Zaključak: Adrenalin predstavlja lek izbora i najbitnije je da bude primenjen što pre je moguće. Međutim, postoje brojna neslaganja među autorima u pogledu opravdanosti primene ostalih, gore navedenih lekova. Takođe, zaključujemo da je intravenska primena kalcijuma prilikom zbrinjavanja pacijenata sa anafilaktičkom reakcijom napuštena.

Ključne reči: histamin, adrenalin, glukokortikoidi, kalcijum hlorid 